Зорица Томић

Универзитет у Београду

Филолошки факултет

\title{
ДА ЛИ ЈЕ АГОН НАША СУДБИНА?
}

\begin{abstract}
Полазећи од античког појма агона као племените вештине надметања, која је представљала окосницу и етос грчке културе, у раду се разматра промена значења ове категорије у оквиру владајуће парадигме савремене културе. Својеврсни антрополошки песимизам који од Хобса, Шопенхауера и Фројда представља човека превасходно као биће борбе, потврђује се у оквиру савремене високо индивидуалистичке културе, као подлога комуникативног модуса у којем Други није саговорник, већ такмац. У раду се показује како савремена култура у потпуности одређена логиком либерално-економског модела и креирана из помоћ медија, суспендујући демаркациону линију између сфере приватног и јавног, опозива антички идеал хероја, и тиме и концепт агона као надметања у изврсности.
\end{abstract} ализам

Кључне речи: агон, култура, природа, моћ, јавност, други, индивиду-

Фројд није значајан за савремену мисао само по томе што је, како је сам рекао, његово откриће несвесног, био један од три снажна ударца људском нарцизму - поред Коперниковог космолошког и Дарвиновог биолошког обрта - већ и зато што је у духу својеврсне песимистичке традиције, а на трагу како Хобса тако и Шопенхауера, изложио тезу о урођеној људској агресивности. Тај антрополошки песимизам, потпомогнут Дарвиновим биолошким детерминизмом, појављује се данас, као готово идеална подлога не само за испитивање тезе о комуникативним ратним играма, већ и о стратегијама агресије или занемаривања Другог, тим пре што са открићем несвесног, Фројд открива и сцену језика, а тиме свакако и сцену комуникације, као поље на којем се одвија комплексна динамика прикривања, откривања и суочавања са агресијом усмереном једнако ка себи и ка другима. 
Фројдова теорија несвесног, метафора о свесном Ја као „врху леденог брега“", напоредо са теоријом о темељним комплексима као конститутивним елементима психичког развоја и социјализације, али истовремено и вера у моћ Ума чији је суштински задатак освешћивање садржаја несвесног, скицирају обрисе људског бића у оквиру једне антрополошке парадигме која га у основи препознање као биће борбе. Почев још од Платона па преко јудео-хришћанске традиције, подвојеност тела и духа, не само да је представљала подлогу на којој ће се касније развити концепт културе као оплемењене и продуховљене природе, већ у Фројдовом делу поприма облик једне вредносне и симболичке вертикале у којој оно природно и анимално, које је истовремено и потиснуто, скривено и неартикулисано треба да буде превладано, култивисано и освешћено. Наиме, сагласно Фројдовој теорији, човек не само да је принуђен да се непрекидно бори са природом како би преживео, већ истовремено мора да се бори и са својом сопственом природом - са природом у себи, анималном, себичном, агресивном и деструктивном - како би могао да живи са другима, односно, како би могао да живи као друштвено и културно биће.

Али, има ли победника у тој перманентној борби? Јер, ма колико се борио са природом, у природи свега живог већ је посејана клица смрти, па је свака таква борба унапред изгубљена. Са друге стране, Фројдов утопијски пројекат артикулисан у тези „где је био Ид нека буде Ја“, концепт истеривања свих „демона из подземља људске душе“, појављује се истовремено у двострукој улози - и задатка и достигнућа културе. Уводећи категорију Ума, Фројд заправо изриче тезу о дуалности људске природе. Људско биће је истовремено и биће нагона, али потенцијално, човек је биће Ума. Идеално стање би се остварило „у једној заједници људи који су свој нагонски живот подредили диктатури ума. Чак и када би се притом морали одрећи међусобних осећајних веза, ништа их друго не би могло тако потпуно и тако чврсто ујединити као ум. Али то је највјеројатније тек једна утопијска нада“.

Занимљиво је, међутим, да многи савремени аутори који се баве култрним феноменима и антрополошким теоријама, упркос данас снажно присутном духу сцијентизма који недвосмислено слави модерна и до сада незамислива научна открића - попут клонирања, ЗД принтовања органа или методе брисања свих непријатних и уз- 
немирујућих сећања из свести - истовремено уводе у дискурс појам изгубљеног људског самопоуздања. Пољуљано Коперниковим епохалним открићем да земља није средиште космоса, изгубљено са Дарвиновом еволуционистичком теоријом са којом љубав Бога према свом најмилијем створу неповратно бледи, Фројдовим опозивом вере у свемоћ људског разума, као и све снажнијим оспоравањем важности традиционалних друштвених веза, попут породице или „правих“ пријатељстава, самопоуздање (може се разумети и као поуздање само у себе, или да се нашалим, „сопство које је наша највећа узданица“) се данас појављује као категорија од које суштински зависи наш идентитет, а својеврсни културни налог о беспоговорном и ,аутономном“ управљању собом и светом који нас окружује, добија кључни значај за наш осећај сигурности.

Али зар није необична толика потреба за сигурношћу, коју у епохи лаке доступности научно развијених механизама и стратегија одбране - од лекова до водоотпорних материјала, преко дезинфиковане хране и планинског ваздуха пакованог у флаше, аларм система и осигуравајућих полиса - испољава човек данашњице? Како је могућно да и поред свих високо развијених сигурносних техника и најразноврснијих стратегија заштите - од физичких до симболичких и даље тако страсно жудимо за сигурношћу? Другачије речено, зашто се толико осећамо угрожени у свету који смо, верујемо, направили по сопственој мери? Да ли данас апсолутно нескривена потреба за контролом, као и за осећањем моћи, происходи заправо из те темељне егзистенцијалне и онтолошке несигурности?

Фројд је у свом делу Тойем и Табу отворио питање о настанку, односно, генези културе, уводећи у оптицај тему „оцеубиства“ као одлучујући и парадоксални обрт, према којем уређени људски свет, односно култура, настаје заправо, као последица дејства „силе нагона“. Наиме, акт оцеубиства, чин којим незадовољни синови у циљу пражњења свог сексуалног нагона убијају тиранског оца како би коначно стигли до женки, резултоваће стварањем уређеног друштва, друштва у којем владају правила.

Од изузетног значаја је, међутим, да се категорија моћи појављује као централна и одлучујућа за ексклузивно људски универзум, односно, културу. Све људске институције које конституишу културу, а 
које настају после тог епохалног „злочина“-закон, религија и савест, представљају различита лица моћи. Тако се може рећи да је категорија моћи у својим различитим оспољењима, први производ култуpe. Али категорија моћи није ништа друго до симболички еквивалент феномена физичке силе који припада Универзуму Природе. Сагласно тези да „ум царује а снага кладе ваља“, сфера природе обележена је голом физичком силом (у Фројдовој студији она је персонификована у фигури Алфа мужјака који као највећи и најснажнији присваја све женке за себе), док је сфера културе обележена категоријом моћи као конститутивном за низ културних, а то значи и специфично људских институција - као што су забрана инцеста, табу као забрана убијања тотемске животиње и коначно, савест као интрапсихичка инстанца.

Аристотелова теза о човеку као о „политичкој животињи“, на коју се свакако ослања и Фројд, претпоставља присуство и препознавање/ прихватање „других“ као услов појављивања људскости. Дубоки социјални корени хуманитета, темеље се најпре на широкој друштвеној интеракцији, која би била немогућа без система симболизације, а пре свега језика, односно, комуникације. Други су непрекидно присутни у нашим животима - стварни и виртуелни, људи из наше прошлости или из митологије - други, без којих нема симболичке размене и организовања искуства у смисаону целину и без којих је немогуће створити слику о себи. Јер људски свет није превасходно свет људских достигнућа, није само свет прогреса и техничке рационалности, већ пре свега универзум замршених релација, комплексних контаката и заједничких искустава.

Други су нам неопходни како бисмо знали ко смо, без њих је немогуће имати појам о сопственом идентитету. Од других који нас окружују добијамо елементе за „слику света“, од њих учимо друштвена правила, језик и начин на који комуницирамо. Када Могли, јунак Кюиїе о иунїли, у истоименом цртаном филму, лежећи потрбушке на стомаку свог пријатеља медведа Балуа који опружен на леђима плута на води, каже за себе „Баш је лепо бити медвед“, он заправо потврђује тезу да су други увек наши репери - истовремено и наше границе али и наши хоризонти - будући нам обезбеђују простор за самопрепознавање и тиме за стицање представе о сопственом идентитету.

Али живот са другима, друштвени живот једном речи, одвија се у универзуму структурисаном на принципу моћи, тог симболичког по- 
ретка који је истовремено и фиксан и флексибилан. Ако је, наиме, свет својевремено био јединствено хијерархијски уређен, тако да је принцип моћи био унапред дефинисан „псеудо-природним“ поретком у којем су се тачно знале социјалне позиције моћних и оних на којима се та моћ оспољавала (робовласници и робови, феудалци и кметови, послодавци и радници), са француском револуцијом и максимом о ,једнакости, братству и слободи“, као и са појавом модерне у чијем је средишту био концепт слободне индивидуе, принцип моћи данас добија потпуно другачије усмерење и интерпретацију. Ако се томе дода и Наполеоново увођење принципа меритократије који се појављује у оквиру нове социјалне и идеолошке парадигме пост-револуционарне Европе, а које је данас оснажено глобалном либерално-економском идеолошком и политичком матрицом - онда не треба да чуди што су традиционално успостављени и неговани друштвени односи претрпели драстичне промене.

Као да се са поменутом променом друштвене и симболичке парадигме, сила урођене људске агресивности размахала у свој својој пуноћи. Хобсово уверење о непријатељској настројености и међусобно супротстављеним тензијама које обележавају људске односе у фази пуке „природности“, као да све више добија на замаху, посебно у форми „супарничке сарадње“ на коју обавезују нови симболички поредак и модерна „радна етика“. Симптоматично је свакако и то што Томас Хобс принцип „,bellum omnia contra omnes“ као модел људских односа у „природном стању“ разумео као неку врсту социјалне „предисторије“ која претходи стварању рационално уређене државе, са сувереном на челу. Можда је неспорна актуелност Хобса данас природна последица владавине либерално-економске парадигме као идеолошке поставке савременог света у којем категорија суверености више не важи за државе и њене институције, већ служи једино легитимацији и огољавању над-националне логике капитала.

Свет суочен са хаосом у којем се демократски изабране владе споља руше под плаштом одбране демократије, прикривајући нео-колонијалистичке апетите над-националних корпорација, свет у којем принципи права и правде бивају обесмишљени пред непопустљивом логиком профита, и у којем се иза рационално одабране аргументације оправдавају варварске политичке и војне интервенције моћних, представља управо мрачни свет од којег је Хобс зазирао. 
Снажење логике капитала у његовој разулареној и нашироко промовисаној форми, упркос заклињању у вредности индивидуалних слобода и индивидуалних избора, резултовало је перверзним заокретом у којем је уместо слављења вредности индивидуалне слободе, људско биће постало тек предмет размене на тржишту вредности и добара. Далеко од сваке еманципаторске праксе коју је наговестио Марх, савремена култура која апсолутизује вредности индивидуе увелико загазивши у „крајњу фазу персонализације“, оставља мало простора за организовање стварне „заједнице“. С правом се можемо запитати како је могућно „опште добро“ када је индивидуум дошао до своје крајње фазе у којој се уместо отворене и слободне друштвене комуникације помаља простор својеврсне „социјалне пустиње“ у којој више нема места за Другог?

У савременој култури у којој тржиште роба и информација регулише све наше односе „бити конкурентан“, појављује се као културни и психолошки императив. Бити расположив на тржишту размене, бити умрежен и бити у игри, што су све заједно наше данашње социјалне и персоналне обавезе, указује да је у раздобљу незапамћеног ентузијазма либерално-економске парадигме, човек, парадоксално, престао да буде привилегована фигура. Идеологија либералног капитализма, заоштрено формулисано, човека види искључиво као слободног појединца, који нема ништа супстанцијално заједничко са другим појединцима, осим способности да се размењује на тржишту вредности и знакова. Али „бити конкурентан“ не значи само себе понудити за тржишну размену, већ исто тако, бити обавезан на непрекидну борбу у свету у којем се сви други претварају у „вучије њушке“. Беспоштедна борба за опстанак на тржишту (тржишних) вредности, уз све манипулативне технике самопромоције, перманентну симулацију сопствених постигнућа (будући да су људи принуђени да се претварају да раде или знају више него што се од њих тражи ), од људског света западноевропске културе огрезле у логици либералног капитализма, направила је крваву арену у којој у најбољем случају не примећујемо друге, а у најгорем морамо да се непрекидно хватамо за гуше како бисмо преживели.

Борба? Не, већ рат до истребљења.

Појам агона, у значењу борбе, надметања, такмичења, ушао је у западноевропски мисаони круг преко античке Грчке културе. Ка- 
тегорија агона, симболички посредована као племенити принцип друштвене комуникације, представљала је заправо темељ на којем ће настати фигура хероја. Штавише, може се рећи да категорије агона и хероја представљају само два лица истог феномена који је обележио грчку културу засновану на темељу категорија изузетности и изврс-

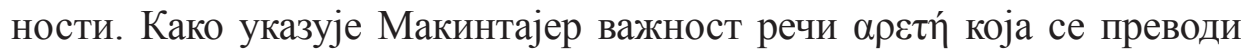
као врлина, за античку грчку културу садржана је у чињеници да се користила да означи изврсност сваке врсте. Јер концепт агона као надметања, такмичења и племените борбе, претпостављао је најпре идеју о врлини, и тиме упућивао на категорију изврсности. Појам изврсности - vлєрохй - интерпретиран као чворно место на којем ће се изнедрити категорија „Племенитог вишка“, био је кардинална одредница фигуре трагичног јунака, тог појединца изузетног како у врлини тако и у вештини, како је писао Аристотел у својој Поешиици.

Идеја надметања, међутим, темељила се на општем и узајамном уверењу да је супарник увек бољи, вештији и изврснији, иначе агон не би имао никаквог смисла. Дубоко узајамно поштовање противника, уверење да борба има смисла само уколико је такмац супериорнији, моћнији и бољи, учинила је агон једном од окосница античке Грчке културе. У таквој констелацији хероизам природно постаје одлика победника, али је херојским духом овенчан и губитник који је часно изгубио од бољег. Витештво надметања без обзира на разлику између компетитивности хомерске епохе и кооперативности атинске, темељило се превасходно на уверењу да се изврсност може потврдити и оспољити само у такмичењу са бољим од себе - не да би се понизио Други, већ да би се дозволило двема изврсностима да се сретну и међусобно упореде.

Витештво надметања као вредност по себи омогућило је развијање три кардиналне институције античке грчке културе - олимпијске игре, театар и парламент. Хероји и победници као узорни модели како у врлини тако и у вештини, овенчани славом и поштовањем рођени су на сцени, која је представљала други значајан конституенс агона. Сцена, без обзира да ли је у питању олимпијско борилиште, амфитеатар у којем се одмерава песничко умеће или пак народна скупштина, није била обичан јавни простор, већ напротив, специјални, посебни, изузетни, ексклузивни простор намењен јавном надметању у изврсности. У извесном смислу, могло би се на трагу Елијадеа рећи да је сцена за- 
право вид светог простора, одвојен од профаног не само стварном већ и симболичком границом.

Категорије јавности уопште и посебно јавног простора, како је то приметио Хабермас не само да су представљале conditio sine qua non демократије, обезбеђујући заштићену сферу privatusa, већ су такође обавезивале све слободне грађане на учествовање у јавном животу полиса. И мада Антички појам демократије претпоставља отвореност јавне сцене за све слободне грађане, грчки етос је претпостављао да је сцена намењена јавном надметању само најизврснијих: свако ко је желео могао је да се окуша на сцени, али су се на такав чин одважили само они који су је доиста били достојни. Тај неизговорени али подразумевајући услов античке грчке културе - бити достојан сценепотврђивао је вредност изврсности и врлине као њених окосница.

Данас, међутим, извесно је да су све категорије на којима се развијала античка култура, неповратно первертиране. Иако је извесно да се наш појам игре као и наши ратови, темеље у извесном смислу на античком појму агона, они се од њега драстично разликују, будући да за антички свет победа некада значи пораз и обратно, јер у суочавању „са смрћу победа и пораз више не деле људе“...“што је прва велика објава моралне истине у грчкој култури“. Агон је централна институција грчке културе између осталог и зато што се агон трансформисао y, рекли бисмо, централно комуникативно начело будући да су категорије политичког, драмског, филозофског, биле снажно међусобно повезане. „Политика и филозофија су имале драмску форму, теме драме су биле филозофке и политичке, филозофија је морала да изађе са својим тврдњама у политичку и драмску арену. У Атини је [...] и сама публика била колективни глумац... Атињани нису изоловали [...] остваривање политичких циљева од драмске представе или постављење филозофских питања од обоје... Отуда нама недостаје, као што њима не недостаје, било каква публика, зајеgница (подвукла 3.Т) са општеприхваћеним схватањима било за драмско представљање политичког конфликта, било за филозофско преиспитивање политике“.

У доба „News Age“, медијске пенетрантности која поништава ту круцијалну демаркациону линију између privatusa и publicusa - у епохи која релативизује све врлине разређујући и парајући смисоно поље у којем се оне препознају и описују, и посебно у култури у којој је 
олимпијство постало ствар политике и врхунског бизниса, позориште и уметност уопште, постали агентура политичке коректности, а херојство индивидуе препознато као учесталост њеног појављивања у медијима, у култури у којој политичари слове као тек привремени и често случајни експоненти интереса мултинационалног капитала антички агон више није ствар моралног јунаштва оријентисаног ка очувању и слављењу концепта општег добра.

Никакво надметање данас није на снази, јер је у свету без хероја немогуће препознати вредност за коју се вреди борити. Ако су за херојска друштва морал и друштвена структура једно те исто, „онда је то због чињенице да су човеково место у друштву одређивале пре свега привилегије које је добијао у односу на статус, али исто тако ако не и више, и дужности према заједници, које су такође биле статусно одређене“.

Како су концепт општег добра а са њим и универзалне вредности хуманизма цинично одбачени у ропотарницу историје - као старомодни реликти једног времена напајаног на превазиђеној и „непродуктивној идеологији људске заједнице“ - никакво огледање у врлини или вештини практично данас није могуће. У култури у којој је операционална још једино „мантра личног интереса“, оснажена идеологијом успеха и „социјалног алпинизма“, у којој су категорије угледа и личног интегритета релативизоване и замењене искључиво потрагом за привилегијама, а категорија дужности заборављена, нема надметања у античком смислу. Чак и када се понегде одвија, племенито надметање без подршке капитала или медијских кућа, интерпретира се као аутсајдерско губљење времена, као чисти аматеризам осуђен да заувек настањује културну и друштвену маргину.

Уместо племенитог надметања, савремена култура отворено слави ,логику екстерминације“ и рат као начело истребљења, промовишући га истовремено и као оптимални модел комуникације. Данас не само да је концепт уважавања опонената обезвређен, већ је уверење да су нам сви Други, од партнера, родитеља, учитеља, колега, комшија па чак и сопствене деце, или само различита средства или пак неумитне препреке на путу креирања једног у потпуности персонализованог универзума, постало општеприхваћени кредо једне насилне комуникативне парадигме.

Отворено је питање, наравно, како је могућно да се данас тако „слабо разумемо“ и поред свих техничких помагала намењених „олак- 
шању“ наших контаката и односа са другима? И да ли наши сукоби са другима происходе из неспоразума који настају као последица бројних социјалних, техничких и симболичких посредовања, у којима ново тумачење захтевају како бука тако и ћутање, не само као њихови интегрални делови, већ и као изузетни комуникативни феномени на којима се оспољавају различити аспекти моћи.

\section{Литература}

Елиаде, М. (2003). Светио и иррофано. Нови сад: Издавачка књижарница Зорана Стојановића

Фројд, С. (1986). „Несвјесно“, у: Буgућносӣ јеgне илузије. Загреб: Напријед Хабермас, Ј., (1969). Јавно мнење. Београд: Култура

Хобс, Т, (2006). Човек и ірађанин. Београд: Хедоне

Липоветцки, Ж., (1987). Доба иразнине. Нови Сад: Књижевна заједница Новог Сада

Макинтајер, А. (2006). Tраїање за врлином. Београд: Плато

Zorica Tomić

\section{Summary}

\section{IS $A G O N$ OUR DESTINY?}

Dealing with the ancient notion of agon as a noble art of competition, which is a central aspect of Greek culture and ethos, the paper discusses the changes in the meaning of these categories within the ruling paradigm of contemporary culture. A kind of anthropological pessimism of Hobbes, Schopenhauer and Freud which represents human world primarily as a battlefield, is confirmed within the contemporary highly individualistic culture, as the basis of communicative modes in which the Other is not an interlocutor anymore, but a contender. The paper shows how contemporary culture - completely determined by the logic of liberal economic model and created by the impact of the media - suspends the demarcation line between public and private spheres, revoking the ancient ideal of the hero, and thus the concept of agon as competition in excellence.

Key words: agon, culture, nature, power, public, others, individualism 